\title{
Claudia Preckel*
}

\section{Cinnabar, Calomel and the Art of kushtasāzī: Mercurial Preparations in Unani Medicine}

DOI 10.1515/asia-2015-1042

\begin{abstract}
This paper examines the role of mercury in "Graeco-Islamic" medicine, which is referred to as Tỉbb-e yūnānī or unani medicine in South Asia. Having its origin in Ancient Greece, unani medicine spread to the Arabic countries and from the fifteenth century onwards to India. With its main roots in the Greek and Latin sources, the most influential works of 'ilm al-adviya (pharmacology) were translated into Arabic, Persian and Urdu. Mercury (Arabic: zībaq; Persian: sīmāb; Urdu: sìmāb and pāra) played an important role in all Indian traditions of medicine, and had a prominent place in unani medicine. This paper highlights the historical use of mercury in Indian, Persian and Urdu medical literature, the discourses on its efficacy and some of the important mercurial preparations presented in a selection of unani works. Further, the use of mercury as a single and compound drug and its role in the treatment of different diseases will be analysed.
\end{abstract}

Keywords: unani medicine, mercury, cinnabar, calomel, kushta (calyx), medical history

India always was (and still is) a country with ethnic, cultural and religious diversity. One aspect of this diversity is reflected in the fact that the government of India supports several co-existing medical traditions, monitoring and regulating their education and practice through the Department of Ayurveda, Yoga \& Naturopathy, Unani, Siddha and Homoeopathy (AYUSH). The medical traditions named in AYUSH's title are considered the most important indigenous traditions of medicine.

This paper focuses on the use of mercury in unani medicine, which is also called "Graeco-Arabic" medicine, "Graeco-Islamic" medicine or simply "Islamic medicine". ${ }^{1}$ The paper describes the development of unani medicine

1 Speziale 2009b. This paper will not discuss the question if there is any "Hindu" or "Islamic" science at all. But it is worth mentioning that authors like the Pakistani nuclear physicist Pervez A. Hoodbhoy denied that there is an "Islamic Medicine". See his 1992 Islam and Science: Religious Orthodoxy and the Battle for Rationality. In this book, Hoodbhoy says that science is universal and not following any religion or ideology

*Corresponding author: Claudia Preckel, Institute for Oriental and Islamic Studies, Ruhr-Universität Bochum. E-mail: Claudia.Preckel@ruhr-uni-bochum.de 
in South Asia and the use of mercury by unani practitioners, the hakims. It also raises the question if (and how) the use of mercury - which is typically associated with Saiva mythology in Hindu medical writing - is explained in an "Islamic" medical system. The focus of this paper is on the sources from the nineteenth and twentieth century, but will also relate to the relevant Arabic and Persian sources on this subject, which are covered by other papers of this volume.

\section{Unani medicine and its history in South Asia}

Throughout South Asia, the English term unani medicine is commonly known as the name of the humoral holistic medical tradition. It is derived from the expression tịbb-e yūnānī, meaning "Ionian" or "Greek" medicine in reference to its roots in Ancient Greece. Today, several other designations of tibb-e yūnānī are common throughout South Asia, for example Eastern medicine, unanipathy, Graeco-Arabic medicine, Islamic medicine, and some others.

The origin of unani medicine lies in ancient Greece, where Hippocrates (Urdu: Buqrāt, d. ca. 371 BC), Aristotle (Urdu: Arisțū, d. 322 BC) and Galen (Urdu: Jalīnus, d. ca. $200 \mathrm{AD}$ ) systematised the theories of the four elements, the temperaments and the humours of the body (explained below). Their writings - most of them in Greek, some in Latin - were translated into Arabic. In ninth-century Baghdad, the Nestorian Christian Ḥunayn Ibn Ishāq (d. 830), known as "shaykh of all translators", translated many medical works into Syriac and Arabic. Later on, when Graeco-Arabic medicine spread to Persia, many works based on the Galenic tradition were further translated into Persian. To include the role of Persian for the development of medicine, one might speak of "Graeco-Islamic medicine", especially in the Indian context.

Today, historians and practitioners of unani medicine agree that two Muslim authors were the founders of unani medicine in the narrow sense: One of them is Muhammad Ibn Zakarīya ar-Rāzī (d. 925 or 932), also known by his Latinized name Rhazes - the other is Ibn Sinna, or Avicenna (d. 1037). Avicenna became known as the "Prince of all Physicians" in Europe, and today this honorary title is also used to describe him. In the Middle East, he is known as al-Shaikh al-ra'ss, "the head or the leading one among the teachers". Rāzī wrote several treatises on medicine in Arabic and Persian, some of them have also been translated into Urdu. ${ }^{2}$ His medical encyclopaedia Kitāb al-Hāwi fi-ț-țibb ("The Comprehensive Book on Medicine”) is

2 Ar-Rāzī 2008. 
one of the most influential books on pharmacology in Graeco-Islamic medicine. Rāzì was also keenly interested in alchemy and wrote two influential works on alchemy, al-Asrār ("The Secrets") and Sirr al-asrār ("The Secret of Secrets"). Both works deal extensively with mercury and also mention its toxicity.

Throughout South Asia, however, the majority of practitioners of unani medicine - if asked which was the most influential work in unani medicine - would surely answer that it was the al-Qānūn fi-ț-tibb "The Canon of Medicine" by Ibn Sīnā. ${ }^{3}$ The second book of the Qanūn is dedicated to single drugs, whereas the fifth book deals with compound remedies. This makes it a valuable source for pharmacology ('ilm al-adwiya) in unani medicine. Indeed, the book was of utmost importance both in the Islamic world and in Europe, where the Latin version was used in the medical school of Salerno until the seventeenth century. Like many other medical works, the Qānūn was translated into Persian and later into Urdu. ${ }^{4}$ During the last centuries, numerous commentaries, abridgements and glossaries of works from the Galenic and Aviennian tradition were written and (re-)printed in South Asia. Until the nineteenth century, Persian remained the lingua franca and scientific language of South Asian, followed by Urdu, which played an important role in the spread of unani medicine.

In the following chapter, the basic principles and concepts of unani medicine will be explained.

\section{Basic theory of unani medicine}

It has already been mentioned that the basic principles ${ }^{5}$ of unani medicine were formulated by Greek scholars like Hippocrates, who stated that the body - like everything in nature - consists of four elements (arkān), namely earth, water, air and fire which have the characteristics of being hot, cold, wet and dry. These elements represent the four humours of the human body, called akhlät in Arabic and in Urdu. These are black bile (sawḍa), phlegm (balgham), blood (dam) and yellow bile (safrā). In every human body, one of these four humours is dominant

3 Ibn Sīnā 1593 (Arabic); English translation of Vols. 1-4, 1993-2002 (New Delhi, Jamia Hamdard).

4 Ghulām Ḥasnayn Kāntūrī published the only complete Urdu version of the Qānūn from 19121930 (Lucknow, Naval Kishore Press), but astonishingly, it never became very popular. There are several manuscripts and editions of the Persian version kept in libraries in Tehran and in the British Library.

5 Azmi 1995; Zillur Rahmān 2001. 
and determines a person's personality or temperament (sg. mizāj, pl. amzija): A melancholic, for example is dominated by black bile, and cold and dry like the earth; a phlegmatic is dominated by phlegm, and cold and moist like water and so on. Although humoral theory is fully aware that each person is dominated by one humour, the equilibrium (i'tidāl) of all humours of the body is regarded as health (Urdu: șehhat). Illness is caused by a state of imbalance of the humours, which is usually induced by the sudden increase of one particular humour in one organ.

Unani medicine has defined six essentials to preserve health, known as asbāb-e sitta żarūrīya in Urdu and sex res non-naturales in European medicine, following Galen. These are air; food and drinks; bodily movement and repose; psychic movement and repose; sleep and wakefulness; and excretion and retention. The preservation of health (Urdu: hifz-e sehhat) is an important part of unani medicine. When a disease occurs, it is diagnosed by a detailed physical examination and by examination of the pulse (nabz), urine (bawl) and stool (barāz). Today, many hakims additionally use blood tests, x-rays or ultrasonic testings. unani medicine knows many kinds of therapies, e.g. the regimental therapy ('ilāj bi-t-tadbir), comprising the Turkish bath (hammām), cupping (hijāma), enema (huqna) or other kinds of sweating and purging; dieto-therapy ('ilāj bi-l-ghidhā'), surgery ('ilāj bi-l-yad) and even psychiatric treatment ('ilāj nafsānì). The most important therapy, however, is pharmacotherapy ('ilāj bi-d-dawā').

Many hakims regard pharmacotherapy as the backbone of unani medicine. They claim that the use of drugs of only natural origin is the greatest advantage of that medical tradition, as these drugs - used properly - have no side effects and are safe.

In unani medicine, there are three sources of drugs (Urdu: makhaz-e adviya): (1) Drugs of animal origin (Arabic: adwiya hayawānīya) like amber, musk, pearl, oyster shell, silk-pod and castoreum. This category comprises animal glands and tissues, and in some cases even the poison of animals (e.g. of snakes).

(2) Drugs of mineral origin (Arabic: adwiya ma'danìya) like metals, metal ores, minerals, and gems. Examples are gold, silver, tin, mercury, cinnabar, iron rust, rubies and sal ammoniac.

(3) Drugs of plant origin (Arabic: adwiya nabātīya), like roots, flowers, leaves, gum-resins, extracts and others.

Like every thing on earth, a drug has a certain degree of temperament (daraja-ye $m i z \bar{a} j$ ), ranging from I-IV. While ancient doctors defined the mizāj of a drug 
according to its effect on the human body, modern authors (since the twentieth century) try to explain the degrees of the temperament of a drug by means of chemistry, biochemistry or physics. The degree of the mizāj is nowadays related to the drugs' toxicity. A degree of I shows no/low toxicity, whereas a drug with the degree of IV is regarded as toxic/poisonous.

In unani medicine, drugs are available either as single drugs (mufradāt) or as compound drugs (murakkabāt). They are usually offered in the following forms:

(1) Solid: pills (habb); tablets (qurș), powders (sufūf)

(2) Semi-solid: These are preparations of a drug mixed with purified honey, jaggery or sugar and stirred. The most famous of this kind are ma'jūn, jawārīsh and khamīra. ${ }^{6}$

(3) Liquid: Syrup (sharbat), distillate ('arq), drops (qatūr)

(4) Vapour: fumigation (bakhūr), inhalation (inkibāb)

Mercurial preparations are often used for fumigations or as pills.

\section{Unani medicine and pharmacology in South Asia}

From the twelfth century onwards, unani medicine spread throughout India. ${ }^{7}$ In Northern India, hospitals following the Hippocratic-Galenic teachings of treatment were established. The Delhi Sultanates (Khilji, Tughluq and Lodhis) opened dispensaries and patronised physicians at their courts. Following the decline of the Bahmanid rule in the Deccan (ca. 1527) physicians from Persia came to the (Shiite) courts of the local dynasties of the Adilshahis, the Nizamshahis and the Qutbshahis. When the Safawid rulers of Persia (r. 1501-1731) made Twelver Shiism the State religion, many hakims left Persia for South Asia, fearing forced conversion to Twelver Shiism or other forms of

6 According to the book Standard Unani Medical Terminology, published by the CCRUM (2012), ma'jūn is "a semisolid medicinal preparation obtained by mixing powdered drugs in a Qiwām (base) made of purified honey, sugar or jaggery" (CCRUM, 2012: 123). Jawārīsh is "a semisolid preparation made by mixing coarse powder of drugs to a base of purified honey, sugar or jaggery. It is particularly used for GIT (i.e. gastrointestinal, C.P.) disorders” (CCRUM, 2012: 125). Khamira is "a type of Ma'jūn obtained by mixing decoction of drugs in a base of purified honey, sugar or jaggery. The decoction is continuously stirred while still hot, till it becomes thick and white" (CCRUM, 2012: 125-26).

7 Alavi 2008; Attewell 2007; Speziale 2009a; Preckel 2015. 
violence and oppression prevalent at that time. They translated many commentaries and works on pharmacology from Arabic into Persian. The historian and physician Muhammad Qāsim Hindū Shāh Firishta (d. 1623), whose family came from Astarabad (Persia) to India, wrote Dastūr al-ațibbā' ("Rules for Physicians") and included many descriptions of Indian plants and the preparations of compound drugs. During the Mughal period (1526-1858), unani medicine was in its peak in India - one might say that it even became a hegemonic medical tradition during this period. During this era, many translations, commentaries or abridgements of Ibn Sīnā's al-Qānūn were made. Abū l-Fatḥ Gilānī (d. 1589), physician and also head of the Mughal provincial administration, wrote an important commentary on the Qānūnchah, which was also used for instruction in the local madāris. Hakīm 'Alī Gilānī (d. 1609), court physician of Akbar, compiled the most comprehensive and extensive commentary of the Qānūn in Arabic.

At the same time, the genre of Qarābādīn (pharmacopoeia) literature flourished, and some of the most important pharmacopoeias were written during the Mughal era. Qarābadin literature is usually named after the author or the person to whom the book was dedicated. For example, Qarābādīn-e Shifā̄i, a very popular pharmacopoeia in Persian, was written by Muẓaffar b. Muhammad Shifā'ì (d. 1556) and Qarābādīn-e Salāmì by 'Abd us-Salām Burhānpūrī (d. 1799). A'ẓam Khān (d. 1903) authored the likewise famous Qarābādīn-e A'zam.

One remarkable example of pharmacopoeia in the Mughal period was the Qarābādīn-e Qādirī, ${ }^{8}$ written by Muhammad Akbar Arzanī (d. ca. 1722). This work was dedicated to 'Abd al-Qādir al-Jilānī (d. 1166 in Baghdad), the founder of the Qādirìya mystical order of Islam, which was of utmost importance in Indian Islam. This highlights the importance of Islamic mysticism for unani medicine during the Mughal period. ${ }^{9}$

Most authors of a qarābadīn arranged the material alphabetically according to the first letter of the drug. Arzānī made an exception from this and arranged the drugs according to the diseases (from head to toe) the drugs were used to cure - within these chapters, the drugs are arranged alphabetically.

During the colonial period, the role of unani medicine again changed. In the beginning of their rule in India, the British were quite interested in all Indian medical traditions and also compiled information about Indian drugs. Many British doctors also claimed that European and unani medicine shared common

8 Arzānī 2008.

9 On this subject see Speziale 2010. 
roots, namely the humoral theory and the teachings of Avicenna. Later, the British tried to replace unani medicine by "allopathy" in the medical curricula of South Asian medical colleges. The London Pharmacopoeia was translated into Urdu, which had become the scientific language of Indian Muslims from the mid-nineteenth-century onwards. Persian qarābādins were also translated and printed in the newly-established printing presses. The Mughal patronage of unani physicians, however, had declined, and unani medicine was only supported in the Muslim Princely States of Bhopal, Hyderabad and Rampur. Some of the most prominent unani physicians of the $19^{\text {th }}$ and $20^{\text {th }}$ centuries were also involved in the Nationalist movements: Hakīm Ajmal Khān, a descendant of Hakīm Sharīf Khān (see above) was a supporter of Mahatma Gandhi and the Indian National Congress. He was also a supporter of the modernisation (tajdid) of unani medicine, e.g. by applying "Western" methods of research on drugs and standardisation of manufacturing. Hakīm Ajmal Khān established the "Ayurvedic \& Unani Tibbia College" in Karol Bagh, Delhi, which is still a famous place for teaching unani medicine. Another famous institution is Hamdard University in Delhi, which was founded in 1906 as a dispensary (dawākhānah) by Hakīm 'Abul Majīd (d. 1922), a pupil of Hakīm Ajmal Khān. Hakīm 'Abdul Majīd’s elder son Hakīm 'Abdul Ḥamīd took over, whereas his younger son Ḥakìm Muhammad Sa'īd (killed 1998) left for Pakistan after Partition. He established the Hamdard (Waqf) Laboratories in Karachi, and later also founded a Hamdard University there. The department for the study of unani medicine is called "Department of Eastern Medicine", reflecting the fact that unani medicine is commonly known as Eastern Medicine in Pakistan. In Pakistan, India and Bangladesh, the hakims still make contributions to the spread of pharmacological knowledge.

In present day India, 42 colleges offer undergraduate studies in unani medicine. The Central Council of Indian Medicine (CCIM) in New Delhi (founded 1970) enforces the standards of education and practice of all formally recognized Indian medical traditions. The idea of government control of the health sector dates back to 1947, when the Health Ministers of the provincial administrations decided to supervise the education and research of the Indian medical systems. In 1969, the Government of India established the Central Council for Research in Indian Medicine and Homoeopathy (CCRIMH) in order to develop education and research in Indian medical traditions, among them unani. In 1978, separate Councils were established, among them the Central Council for Research in Unani Medicine (CCRUM), which is responsible for clinical research, patenting of drugs or drug standardization in unani medicine. The CCRUM has 23 institutions in different parts of the country. Since 1995, ayurveda, yoga, unani medicine, siddha, and homoeopathy (and most recently, sowa rigpa) have come under 
the jurisdiction of the Department of AYUSH, Ministry of Health and Family Welfare, Government of India.

The Unani Pharmacopoeia Committee (UPC) was set up to compile the Unani Pharmacopoeia of India and to establish and enforce rules and regulations for the standardization of drugs in order to keep up the safety of unani medicine. The CCRUM is the Secretariat for the UPC. The CCRUM has also translated, edited and published several important pharmacopoeias and medical encyclopaedia of unani medicine, mainly in Urdu. Thus, we have a comprehensive literary base for the analysis of the role of mercury in unani medicine.

In unani medical encyclopaedias, articles on single drugs usually start with mentioning the name of the drug in different languages. In historical works (especially those from the late nineteenth century onwards), this usually means that the Arabic, Persian and "Hindi" or "Hindustani" names are mentioned. In some works, "Hindi” means Sanskrit, in some cases the (historical) forerunners of Hindi or other vernacular languages are meant: This question should be subject of further research. "Hindustani", however, alludes to the use of Braj Basha or Urdu. From the late nineteenth century onwards, the drugs are mostly arranged by their Urdu names. Additionally, (more) recent unani publications even record the English and Latin names of the drugs. In the case of herbs, this means the names of the plants are classified according to the Linnaean taxonomy, set up by Carl von Linné (d. 1778) in his work Systema Naturae. Von Linné's classifications are still in use in South Asian works on unani.

\section{Mercury as a single drug}

In his Makhzan al-mufradāt ("Treasure-house of Single Drugs", ca. twentieth century), Hakīm Lōdhī lists the following names for mercury:

Latin (lāțīnī): Hydrargyrum; Arabic: zībaq; Persian: sīmāb, Sindhi: pāro parā’̀̄; Gujarati: pāro; Sanskrit: rasrājj, ${ }^{10}$ English (angrīzī): m-r-k-r-y, mercury; Hindi: pāra. ${ }^{11}$

These names are further confirmed in other works like the Tahqìqāt-e khawā aladviy $a^{12}$ and other recent medical encyclopaedia. Whereas these modern works

10 This translates as "the king of liquids".

11 Lodhī s.d. 265-266.

12 Nașīr Aḥmad Ṭāriq s.d.: 183-184. 
on unani medicine confirm that the Persian name of mercury is sima $\bar{a} b$, many Persian-writing authors also used the words zabiq or zibaq, which originates in the Arabic language.

After mentioning the different names, usually the characteristics (mat) of each particular drug are given. Afterwards, the nature (tabi'at) of the drug is mentioned - in some sources, the word mizāj, "temperament", is used. It comprises characteristics like hot and cold and wet and dry, and usually gives a degree of these characteristics.

Interestingly, the sources are quite inconsistent regarding the mizāj of mercury: While mercury is defined as hot and dry in the second degree in the Qānūn, the author of Makhzan al-adwiya ${ }^{13}$ states that it is cold in the second degree and wet in the third degree. South Asian authors, however, hold the opinion that it is hot and dry in the third degree. ${ }^{14}$

All sources agree that mercury is very useful against diseases caused by an abundance of coldness and wetness, and the older (Persian) writings stress the "heating" and "astringent" therapeutic actions of mercury. Mercury is said to be very useful in the treatment of ulcers, especially those associated with syphilis. ${ }^{15}$ It is also used in the treatment of hemiplegia, facial palsy or spasms. ${ }^{16}$ Especially in the latter diseases, mercurial preparations for external use are recommended. Mīr Ṭufayl Aḥmad and 'Aqīlī Khorāsānī (writers of the eighteenth century) both mention the "oil of mercury" (roghan-e zabìq or roghan-e simāb) for treatment. ${ }^{17}$ As both books mainly deal with simple drugs, there is no detailed description of obtaining "oil of mercury" - but two different kinds of preparing roghan-e sīmāb are given by Hazārah Khān. He recommends the preparation of this oil by burning the "clean" mercury with different herbs.

13 The famous Persian book (with the Arabic title) Makhzan al-adwiya ("Store-house of Medicines"), a pharmacological dictionary on simple drugs, was compiled by Muhammad Ḥusayn 'Alavi 'Aqīìi Khorāsānī Shirāzī (d. 1790). He was the grand-nephew of 'Alavī Khān Shirāzī (d. 1749), a likewise famous ḥakīm who migrated from Shiraz to India, where he became ḥakim at the Delhi court. 'Aqīīi Khorāsānī 1844: 483.

14 Nașīr Aḥmad Ṭāriq s.d.: 183; Lōdhī s.d.: 265.

15 It should be added, however, that 'Imād al-Dīn Mahmūd al-Shīrāzī in his Risāla-yi āteshak (Treatise on Syphilis) criticizes the treatment of syphilis with mercury by European physicians as dangerous and non-professional. See Elgood 1931: 477f. I thank an anonymous reviewer for bringing this reference to my attention.

16 From the early 20th century onwards, many unani authors use the English names either for drugs or for diseases. Facial paralysis is also known as Bell's palsy, named after Charles Bell (d. 1842). The unani term is fālij. In his works, Rāzī gave a detailed case study of this disease. 17 Mīr Tufayl Aḥmad 1959: 279; 'Aqīlī Khorāsānī 1844: 483-484. 
It seems the authors of the eighteenth century preferred the external use of mercurial preparations. However, Ḥakīm Akbar Arzānī who was more acquainted with the Persian and Arabic writings of the Indian traditions, mentions several preparations for internal use, for example habb-e simāa or 'uqd-e simmāb. When comparing the preparation of Arzānì's habb-e simmāb ${ }^{18}$ and that in the CCRUM's Unani National Formulary, ${ }^{19}$ there is a great difference in ingredients and the purpose of use: Arzānī recommends habb-e sīmāb for the thickening sperm, whereas the CCRUM prescribes it as a blood purifier. Unfortunately, we have no available data about the kinds of preparations present-day hakims use. The big unani manufacturing companies, however, have to apply the methods given by the CCRUM.

All the sources on the use of mercury in unani medicine stress the importance of using purified material only. In his work on calcination (taklīs; see below), Ḥakīm Ajmal Khān wrote that ḥakīms must use purified (șāfi) mercury only. The purification of mercury for medical purposes required the development of several techniques, which both ayurvedic and unani practitioners applied. Ḥakīm Ajmal Khān mentioned altogether eight different ways of purifying mercury, some of which he considered to be applied by ayurvedic practitioners, some of them used particularly by unani practitioners. The following three methods are recommended in the National Formulary of Unani Medicine:

There are three following methods of purifying seemab (mercury, C.P.)

(a) Seemab is ground with half burnt brick pieces for 12 hours. It is then washed with water and Seemab is separated. The whole process is repeated three times. ${ }^{20}$

(b) Seemab is kept in a four layer thick cloth bag (50 count) and squeezed out by pressing with hands. This process is repeated till the blackish tinge of seemab completely disappears.

(c) Seemab is ground with turmeric powder as long as the powder does not change its original colour. The resultant product is called seemab mudabbar. ${ }^{21}$

It is not known which kind of method for the purification of mercury the majority of hakims use today. The importance of purifying it before further processing it, is undoubted until the present day.

There are some other processes of preparing mercury for medical intake, which will be discussed in the following chapters.

18 Arzānī 2008: 580, 599.

19 CCRUM 2007: 23.

20 CCRUM 2007: 187.

21 CCRUM 2007: 186. 


\section{5 "Sublimating", "binding" and "killing" mercury}

\section{1 "Sublimating"}

As one can see from N. Bachour's paper in this volume, the authors writing on mercury in Arabic stressed the necessity of using processed mercury in order to make it easily absorbed by the human body. In the Arabic sources, mercury is described to be either "sublimated" (mușa"ad) or "killed" (maqtūl) - but the exact differences are not always clear and the words are often used as synonyms. The only thing, which is quite obvious, is that mercury is processed with vinegar, oils or certain plants. It is often burnt together with other substances.

Looking at the Indian sources, the situation is quite similar. In unani medicine, there is a certain kind of process for sublimating certain drugs like camphor (kafūr), raskapūr (or "raskapoor", see below) or sulphur (gandhak). The process of sublimation is called tas 'ìd, which is derived from the second stem of the Arabic $s^{-}-d$, meaning "to allow something to evaporate". In Urdu, it is called jauhar kā udāna. The products obtained in this process are called jauhar. A jauhar is considered a very efficacious drug. According to the Central Council of Research on Unani Medicine, it is prepared in the following way:

\section{Method of Preparation:}

The drugs are ground to a fine powder with sharab (Brandy). The powder is then put in one of the earthen discs having smooth edge and covered with the other disc (apparatus). Thereafter, the discs are sealed air tight with the process of gil-e-hikmat. ${ }^{22}$ The whole apparatus (discs) is then put on a low fire and at intervals it is moistened with water-soaked cloth in order to condense the material deposited inside the upper disc. The apparatus is then taken off the fire and allowed to cool. The process of condensation of $72 \mathrm{~g}$ of the powder drug takes 4 hours. After complete cooling, the apparatus is opened and the sublimate (jauhar) sticking inside the upper disc is scraped and collected. $^{23}$

In the National Formulary of India, the CCRUM gives the composition of eight jauhars, three of which contain mercury and mercurial preparations. The first reads as follows:

22 This is also known as Philosopher's clay, which is composed of clay, cotton, and rice bran. For its use in the production of kushta see Zillur Raḥmān 2009: 83.

23 CCRUM 2007: 37. See also Zillur Raḥmān 2009: 82. 
(A) Jauhar-e kalan ${ }^{24}$

1. Raskapoor $10 \mathrm{~g} .{ }^{25}$

2. Summ-ul-far $10 \mathrm{~g}$.

3. Darchikna $10 \mathrm{~g}$.

4. Seemab $10 \mathrm{~g}$.

5. Shingraf $10 \mathrm{~g}$.

6. Sharab khalis Q.S. ${ }^{26}$

7. Araq-e gulab Q.S.

This means that jauhar consists of subchloride of mercury (i.e. $\mathrm{Hg} 2 \mathrm{Cl} 2$ : mercury (I) chloride, mercurous chloride or calomel), white arsenic (tri-) oxide, perchloride of mercury (i.e. $\mathrm{HgCl}$ : mercury(II) chloride, mercuric chloride or corrosive sublimate), mercury, cinnabar, "pure alcohol" and pure rose water. Jauhar-e kalan is used as a blood purifier, especially in the treatment of syphilis (äteshak). The recommended dose is $30 \mathrm{mg}$ in a capsule.

The second sublimation mentioned by the CCRUM is the "Sublimation of Mercury", Jauhar-e seemab.

(B) Jauhar-e seemab ${ }^{27}$

1. Seemab $25 \mathrm{~g}$.

2. Samm-ul-far $25 \mathrm{~g}$.

3. Raskapoor $25 \mathrm{~g}$.

4. Darchini $25 \mathrm{~g}$.

5. Namak $100 \mathrm{~g}$.

6. Araq-e leemu Q. S.

It consists of mercury, white arsenic (tri-)oxide, subchloride of mercury, cinnamon, salt and lemon juice. Like jauhar-e kalan, it is also used as a bloodpurifying and anti-inflammatory remedy. It is primarily used against scrofula ${ }^{28}$ (khanäzïr) and fistula (nasūr). The recommended dose is 15 to $30 \mathrm{mg}$ in a capsule.

24 CCRUM 2007: 41.

25 CCRUM defines raskapoor as subchloride of mercury. For a detailed use of it in unani medicine, see the chapter below. For its use as an antisyphilitic in ayurvedic medicine see Dagmar Wujastyk's paper in this volume and Wujastyk 2013.

26 The abbreviation Q.S. stands for the Latin “quantum satis", meaning "as much as needed".

27 CCRUM 2007: 43.

28 Also known as mycobacterial cervical lymphadenitis. 
The third one is the jauhar-e tila ("the sublimation of gold").

(C) Jauhar-e tila ${ }^{29}$

1. Burada-e tila ${ }^{30} 10 \mathrm{~g}$.

2. Seemab $10 \mathrm{~g}$.

3. Naushadar $10 \mathrm{~g}$.

4. Sirka-e angoori Q.S.

This jauhar consists of powder of gold, mercury, sal ammoniac and grape vinegar. First, the gold powder is ground with the mercury, then the sal ammoniac and the grape vinegar are added and all substances are rubbed together. After the substance has dried, a kushta (see below) is prepared of it. Jauhar-eTila is an approved remedy against asthma (dì $q$ ), fever (humma) and scrofula. The recommended dose is from 15 to $30 \mathrm{mg}$ in a capsule.

\section{2 "Binding"}

Several Urdu books on alchemy and unani medicine describe the process of "binding" mercury. ${ }^{31}$ As D.G. White has explained for the use of mercury in siddha and ayurveda, the purpose of binding mercury for medical use is the

fixation of mercury, which, like swooning, leaves mercury stable and thereby manipulable, in a state in which it is not subject to evaporation, even when heated over fire. Left unbound, mercury remains volatile whenever it is exposed to heat or sunlight. Once purified, it can be "fixed" via any of the twenty-five or twenty-six alchemical bandhas. Each of these bandhas has a specific medical application. ${ }^{32}$

Unani medicine also knows the process of binding metals, or "making them steady". Some authors use the Arabic word 'aqd for binding: there are several books on the binding of mercury, which show the importance of this subject.

In his book Asrār sīnah bah-sīnah, ${ }^{33}$ Hazārah Khān mentions three different methods of "making mercury permanent" ( $q \bar{a} ' \bar{m})$. One of them is the following:

29 CCRUM 2007: 43.

30 In unani medical terminology barāda (or sometimes: borāda) means the powder made of a drug of cold (barid) temperament.

31 Among them the following book from the British Library, which was not available for a detailed examination of this subject: Hamīd ud-Dīn 1902: 'Aqd as-sīmāb ("The Binding of Mercury").

32 White 1996: 266.

33 Hazārah Khān 1902. The title of the book means "Secrets from heart to heart", which is an expression also known from the context of Islamic mysticism and also emphasises the role of a "secret" science or even to hermeti. The title also obviously alludes to the works of Rāzi. 
Take the same amount of sal-ammoniac (naushadār), sulphate of iron (kasīs), arsenic trioxide (sankhiyā), ${ }^{34}$ borax (sohāga), mercury (pāra), grapes (munaqqā), and alum (phitkain); grind them altogether; put them in a copper vessel wrapped and covered with a cloth smeared with earth. Put it on the fire. After that, rotate the ${ }^{\star \star \star} .{ }^{35}$ This is an approved method (mujarrab). ${ }^{36}$

Once the process of binding the mercury is finished, the compound mixture (tarkīb) can be used as a base or ingredient for the production of other drugs.

\section{3 "Killing"}

The "killing" of metals, (Urdu: mārnā, Sanskrit: māraṇa) means that the drugs are prepared for internal use. Mercury is heated with other metals, salts, and herbal preparations until it turns into ashes, which is supposed to make them easy to absorb by the human body. After being "killed", the mercury loses its "fluidity, density, luster and brilliance". ${ }^{37}$ The process of "killing" metals was (and still is) done in special furnaces, special kilns or wood fired bhattis. ${ }^{38}$ The traditional method of killing metals, however, was to simply put the vessels on a fire made of cow dung cakes. Half of the cow dung cakes should be placed in a pit, followed by dung, and then the other half of the dung cakes. The place for killing metals and preparing kushta (see below) should be safe and secure from wind - otherwise the heat might not be distributed well, and the preparation might remain incomplete. Tariq, quoting Hakīm Kabīr ud-Dīn, recommended that only experienced persons should prepare kushtajāt - only those people were aware of the fact that the cow dung cakes have to be ignited from all sides simultaneously. ${ }^{39}$

The process of producing kushtajāt, called kushtasāzi in Urdu, is considered so be a special art of unani pharmacology. The kushta of mercury, kushta simāa , is considered to be a very efficacious drug. Before the main characteristics and

34 Also known as sammul fär - this Urdu expression is used in the description Nr.1, on page 61 35 Here, the meaning of the text is not clear. It reads jaubarūn - which cannot be explained. It might be jauharūn, which means: the "substances" or the "sublimates", which obviously makes sense in this context. However, the question about the difference of a sublimation of mercury and binding it still arises.

36 Hazārah Khān 1902: 61.

37 White 1996: 267. The sources of unani medicine emphasise the same purpose. See Tariq 2014: 21.

38 Tariq 2014: 21.

39 Tariq 2014: 23. 
the therapeutic use of this remedy are described, a definition of kushta and the art of kushtasāzī in South Asia should be given.

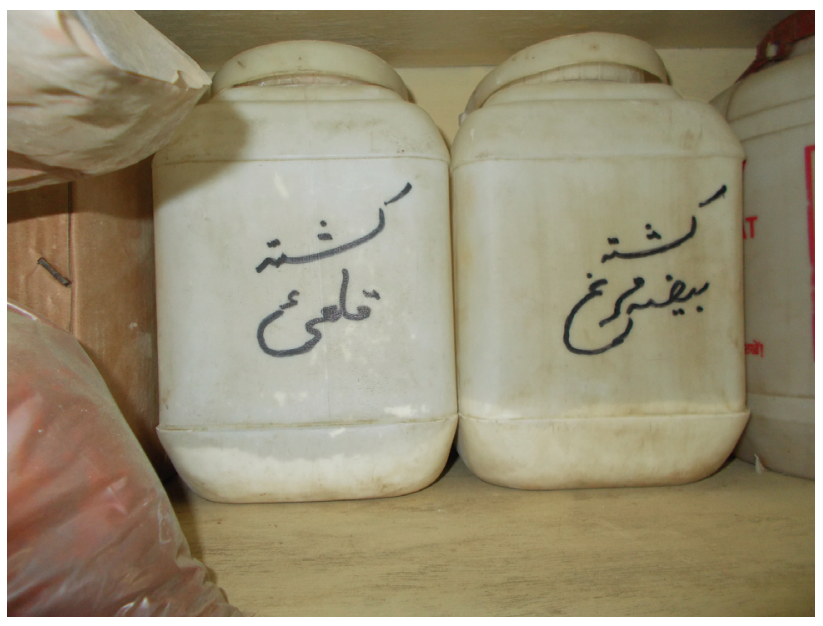

\section{Kushta and the art of kushtasāzi}

The word kushta is derived from the Persian word kushtan, "to kill". It is the perfect participle of this verb and thus means "killed" or captured. In the terminology of unani medicine, kushta (plural: kushtajāt) is the name of the substance obtained by calcination (taklis), ${ }^{40}$ and can be translated as calyx in English. The effect is achieved by "heating a substance at high temperature (but below the melting point) causing a loss of moisture, reduction or oxidation." 41 During this process of calcination, calcium carbonate (limestone) decomposes to calcium oxide (lime) and carbon dioxide. Calcination is applied to metals like gold, silver, tin, copper and mercury and to substances like arsenic trioxide or other salts and minerals. The kushtajāt made of precious stones and gems deserve special attention, they are made e.g. from ruby (yaqūt), ${ }^{42}$ emerald (zamarū $)^{43}$ or jade (yashab). ${ }^{44}$

40 Some books on taklīs are quite rare and are not available to me, e.g. Ḥakīm Kabīr ud-Dīn (s.d.): Kitāb at-Taklīs. Na'ī Dehlī: CCRUM; or the book written by Ibn Sīnā on this subject (some editions). 41 Zillur Rahmān 2009 : 82-83; Tariq 2014: 21.

42 Hazārah Khān 1902: 113.

43 Bulāqī Das 1892 (1): 89, (3) 151.

44 Hazārah Khān 1902: 105. 
Regardless of the origin of the drug to be calcinated (animal, metal or mineral origin), the result is a fine powder, which is usually white in colour, odourless and tasteless.

Concerning the aims and advantages of calcination, many authors on unani medicine agree upon the fact that the process of taklis removes "undesirable parts" and the toxic effects of drugs: For example, fluids contained in crabs and stag horn and poisons of snakes and scorpions are eliminated. It is said to increase the intensity of the particular drug, its efficacy and potency are raised at the same time. ${ }^{45}$ Hakīm Kabīr ud-Dīn (again quoted by Tariq) mentioned several advantages ${ }^{46}$ of kushtajāt: They can be considered highly efficacious in action, but are given only in a very low dose. Compared to other drugs, they are easy to use. In some diseases, the patient might not be able to take large doses of medicine, but kushtajāt can be easily taken. Due to their efficacy, they can also be taken in severe diseases. Another advantage is that the shelf life of kushtajät is unlimited, meaning that they can be stored for an infinite period of time. Some say that they become even more efficacious after a long time.

When it comes to the history of kushtajāt in South Asia, it has to be stated that the discourse about the intake of metallic and mineral drugs (and especially of mercury) dominated the medical discourse in South Asia at the end of the nineteenth century. As can be seen in the sources quoted below, the question of kushtajāt and bhasmas became a matter of distinction between the different medical traditions. Many practitioners claimed that kushtajāt were an ayurvedic invention and identical with ayurvedic bhasmas. Hindu scientists like Dutt focused on the fact that the use of mercury was traditionally rooted in Hindu mythology and therefore concluded that the Hindus invented the use of mineral drugs for internal usage. Dutt also contended that hakims focused on the dangers of those drugs and did not prescribe them:

We cannot help admiring the ingenuity and the boldness of the Hindu physicians, when we find that they were freely and properly using such powerful drugs as arsenic, mercury, iron, etc., when the Mussulman Hakims around them with imperial patronage and the boasted learning of the West, recording such remarks as the following:

"Soomboolkhar, 'the white oxide of arsenic' (...) The Yunani physicians do not allow this to form a part of their prescriptions, as they believe, it destroys the vital principle. The physicians of India, on the contrary, find these drugs more effectual in many disorders, than others of less power, such as the calx of metals. For this reason too, I am in the habit of seldom giving these remedies internally, but I usually confine my use of them to

45 Several authors quoted by Tariq 2014: 23.

46 Tariq 2014: 23-24. 
external application and as aphrodisiacs which I prescribe to a few friends, who may have derived no benefit from Yunani prescriptions. It is better however to use as few of them as possible." ${ }^{47}$

\section{Dutt continued:}

Para, 'Mercury.' It is very generally used throughout India in many ways, both in its native and prepared state, but in the latter we ought to be very cautious, for it is seldom sufficiently killed or removed from its native state, in which it is a dangerous drug. ${ }^{48}$

The "remarks" on the use of oxide of arsenic and of mercury are quotes, which Dutt took from a very popular work on unani medicine, namely the Ta'lif-e sharif ("Publications of Sharîf") by Sharīf Khān (d. ca. 1807), ${ }^{49}$ who was a very influential hakim at the Mughal court and the founder of an important dynasty of unani physicians as well. Ta'lif-e sharif is a dictionary of Indian simple drugs. An English translation by George Playfair ${ }^{50}$ was published in 1833 under the title Taleef Shereef, or Indian Materia Medica. By quoting Sharīf Khān's famous work, Dutt implied several conclusions. First of all, he stated that unani medicine was strong only because of the patronage at the Mughal court and, later, by the British, who, like Playfair, supported it by translating several important works. Its own practitioners did not believe in their own traditions and regarded their drugs, like the "calx of metals" (sic! C.P.) as weak. Dutt further implied that unani practitioners often did not successfully treat their patients with their own drugs, and in this case use those of the "Hindu physicians", who have always propagated the intake of drugs of mineral and metal origin, especially the use of mercury. According to Dutt, it was only the "Hindu physicians" who had developed special methods of preparing mercury for intake.

By contrast, modern authors on this subject - like Tariq - emphasise that it was the Hindus who did not often use the drugs of animal or mineral origin. He states that the Hindus "were not quick in learning the art of adopting the metals and metallic compounds for medicinal purposes." ${ }^{51} \mathrm{He}$ further writes that alchemy and the preparation of metals for medical use only came to India with the Mughal conquest and the works of ar-Razī and others. ${ }^{52}$ It can also be

47 Dutt 1922: xiv.

48 Dutt 1922: xiv.

49 Speziale 2009c.

50 For some remarks on Playfair's translation, which was far more than that, see Arnold 2002: 47-48.

51 Tariq 2014: 18.

52 Tariq 2014: 15. 
stated that Mīr Tufayl Aḥmad and 'Aqīlì Khorāsānī, who wrote in the eighteenth century, confirmed the use of kushta of mercury, but without mentioning the sources of preparations. As both authors were part of the Persian tradition, it can be stated that the art of kushtasāzi (preparation of kushta) was well-known in Persia. Further books of the Persian/Arabic tradition, like the famous Persian work Zakhīrah-ye Khvārazmshāhī by Sayyid Ismā'īl al-Jurjānī (d. 1136) ${ }^{53}$ give proof that kushtasāzi was known throughout the Islamic world, before wider Muslim conquests in India. It might be said that the methods of preparation of kushtajāt changed in the Indian context, and new materials and apparatus were added. Sometimes, new methods were involved, too. It is quite noteworthy that Tariq even claims that the kushtajāt of unani medicine and the bhasmas of ayurveda are the same, and that bhasma is a synonym of kushta. ${ }^{54}$ On the other hand, in the late nineteenth century authors like Bulāqī Das supported the theory that the roots of kushtasāzi lie in ayurvedic literature written in Sanskrit. He emphasised that the aim of his book Iksir-e kushta was to provide knowledge in Urdu about kushtajāt, which was only given in ayurvedic literature. He said that especially to English doctors, this particular knowledge was "strange and wonderful" ('ajīb o-gharīb), as the substances used in kushtajāt were not known to them. Concerning the practitioners of tibb-e yūnānī, Bulāqī Das claimed that they were "defective" (naqașs in this subject. ${ }^{55}$

It should have become quite obvious that the use of kushtas only became a matter of distinction between the various Indian traditions of medicine in the nineteenth century. It is also clear from the sources that both ayurvedic and unani practitioners used drugs of mineral and metal origin. Many hakims used different kinds of kushtajāt, and consider the kushta simāab a very potent and efficacious drug. In the following chapter, the preparation and therapeutic use of kushta simāb will be explained.

\section{Production of kushta sīmāb and its therapeutic use}

Pandit K.D. Sharmā wrote that preparing kushta sìmāb was an art (fann), and in his book on taklīs, Hakīm Ajmal Khān added that it was quite difficult and only

53 Tariq 2014: 13, 118. For the Persian tradition see also Johannes Thomann's paper in this volume.

54 Tariq et al. 2013: 14-15.

55 Bulāqī Das 1892 (1): 1. 
few hakìms were able to prepare it correctly. ${ }^{56}$ It is noteworthy that Bulāqī Das gave only two methods of preparation of kushta simā $b,{ }^{57}$ whereas he mentioned ten methods for other kushtajāt, e.g. that of iron. In the book Asrār sinnah bahsinah, Hazārah Khān, however, listed twenty different kinds of preparing kushta simāb, which shows the importance of this particular kind of kushta for unani medicine. Among the preparations are the following:

(5) Put quicksilver: 5 tōla; sulphuric acid (tēz-āb-e gandhak): 2 tōla; and 25 tōla of nitric acid (aqua fortis, tēz-āb shora) into the distillate of red amaranth ('araq-e surkh chōlā'î) put it on the fire and give heat to it - and it will be the approved (mujarrab) kushta sīmāb.

(9) Quicksilver 5 tōla, sulphur (gandhak) 5 tōla, sal-ammoniac (naushādar) 8 tōla, tin (qal ‘̄) 3 tōla; first rub the tin and the quicksilver together, after that rub the sulphur and the salammoniac separately. Pour all four together in an earthen vessel and put it for 6 hours on a fire. Make a very small hole in the middle of the vessel. [Keep it on the fire] until the smoke vanishes. This is an approved method (mujarrab). ${ }^{58}$

There is a reason why more than twenty different methods of preparation of kushta simāb are given: The effect of the kushta depends on the method and the other ingredients used. Tariq mentioned the example of kushta sammulfar, which acts as an aphrodisiac when prepared with cow milk, clarified butter and eggs, whereas it makes the semen thick when prepared with opium and thorn apple (Datura alba). ${ }^{59}$ Unfortunately, Hazārah Khān did not mention the particular medical action of the different kinds of kushta simāb - and modern unani medical encyclopaedias also usually leave them out. It would be worth translating all these different kinds of preparations in order to know more about their particular use.

Bulāqī Das wrote that it was of utmost importance to clean (șâf karna) the mercury properly before starting the process of calcination. ${ }^{60}$ After that, the whole process of obtaining the kushta has to be done with utmost caution. If this is not the case, pustules and boils will come forth on the whole body. When the mercury is killed properly, the kushta is considered a safe and potent drug and the dose given can be low: ${ }^{61}$ Thus, the dose of the powder of kushta simāb was 1-2 chāwal, which is equivalent to 1-2 corns of rice. The temperament (mizāj) of most kushtajät is considered to be hot and dry (garam o-khushk), the same as

56 Sharmā s.d.: 387; Ajmal Khān 1992: 1979.

57 Bulāqī Das 1892 (1): 78-79; 94-95.

58 Hazārah Khān 1902: 56, 57.

59 Tariq 2014: 21-22.

60 Bulāqī Das 1892 (1): 94.

61 The following chapter is a synopsis of Nașīr Ahmad Ṭāriq s.d.: 183; Lōdhī s.d.: 265. 
that of kushta simāb. This is the reason why it is considered very useful in all kinds of pain and diseases caused by an excess of phlegm (balgham). These amrāż-e balghamī ("phlegmatic diseases") are, for example:

Hemiplegia (fälij), facial paralysis (laqwa), spasm (tashannuj), catarrh and sinusitis (nazla o-zukām), coughing (surfa) and shortness of breath/ asthma (żi $q$ an-nafas). Further positive effects of kushta simmāb are induced in those illnesses caused by the "putrefaction of the blood" (fasād-e khūn), like leprosy (juzām), syphilis (äteshak), ulceration of the lungs and hectic fevers. This is due to its efficacy as a blood purifier (musafi-ye khun). Kushta simāb is also known as an aphrodisiac (muqawwī-yi bāh), and it causes the semen to be held back and makes it thicker (mumsik o-mughliz-e mani). It further strengthens the stomach (kiram-e shikam) and it is a very potent "killer of bacteria" (qātil-e jarāthīm).

\section{Mercurial preparations: cinnabar (shingraf) and calomel (raskapūr)}

In nature, there are several drugs of mineral origin which contain mercury. As will be seen later, in recent times, these substances are usually industrially produced.

The most prominent example of a mineral drug containing mercury is cinnabar (HgS: mercury(II) sulfide, or red mercuric sulphide). It is a compound of sulphur and mercury and one of the few mercury compounds which occurs in nature.

One can obtain mercury from burning cinnabar. This process was described by al-Bīrūnī, (see above) whose works are still well-known in India today. He wrote:

It (mercury, $\mathrm{CP}$ ) is produced from red stones, which are heated in the oven until they disintegrate and mercury rolls from the outlet. Others pound the stones and distil them in a distillation-type equipment in the form of cucurbit and alembic; mercury is collected in the receiver. $^{62}$

This procedure is still known in unani medicine. Hakim Ajmal wrote that a very good method of getting purified mercury is to obtain it from cinnabar. But, he added, this is quite problematic, because cinnabar is quite rare. ${ }^{63}$ One consequence

62 Abū Rayḥ̄an Muḥammad b. Aḥmad al-Bīūnī, Kitāb al-jamāhir fi ma'rifat al-jawāhir, Ḥaydarābād 1936, English translation quoted from Hassan et al. 2001 2001: 96.

63 Ajmal Khān 1992: 181. 
of this is that the cinnabar that can be bought in the bazaars of South Asia is usually not the natural one, but is produced from mercury and sulphur. While artificial cinnabar was produced in China from the Middle-Ages, industrial production of it in Europe started only at the end of the eighteenth century. This procedure was described by Fleming, a British surgeon in nineteenth century Bengal. ${ }^{64}$ Fleming wrote that "the natives" first triturate mercury and sulphur together until black sulphurate is formed. Then, the substance is put into an apparatus of two glazed earthen pots, of which one - inverted - is luted to the other by clay. These are put on fire and later cooled down - the result is a "cake of cinnabar" adherent to the surface of the upper pot.

Today, there are several different methods for obtaining cinnabar from mercury and sulphur, which can be easily assessed in the different works on 'ilm al-adviya ("the science of drugs"). ${ }^{65}$

Apart from its use as a paint pigment (vermillion), cinnabar has long been used for medical purposes. It is still very popular in unani medicine today. It is known as hingula in Sanskrit and Hindi and as shingraf in Urdu. The word shingraf itself is of unknown origin, some people say it might be derived from the Persian zinjīfrah, meaning “dragon's blood”. It might also be derived from the Sanskrit word sindura - sendur being the name of red lead oxide but also of oxide of mercury.

Like most of the metals used for medical purposes, and due to its percentage of mercury, shingraf has to be detoxified before it is used. According to the National Formulary of Unani Medicine, the following process has to be done to obtain shingraf mudabbar ("detoxified shingraf"): "Shingraf is ground with fresh limejuice ( $\bar{a} b$-e limmu $)$ until it is completely absorbed and a fine powder is obtained. This process has to be repeated three times."66

M. Dehlvi describes the process of obtaining purified cinnabar as follows:

Purified cinnabar is prepared by grinding cinnabar with goat's milk for over 6 hours, followed by grinding this mixture with lime juice for one hour. This process is repeated 7 times till a fine powder is obtained. ${ }^{67}$

Dehlvi further states that cinnabar "causes an increase in the number of red blood corpuscles while the body gains weight and the general nutrition is improved." It is also recommended in "anaemia, arthritis, (...) bilious

\footnotetext{
64 Fleming 1810: 51.

65 For example, M. Najm ul-Ghanī Rāmpūrī s.d.: 912-913.

66 CCRUM 2007: 186.

67 Dehlvi 2011: 65.
} 
disorders, (...) liver dysfunction, phlegmatic cough, premature ejaculation (...) sexual debility and syphilis., 68

Like mercury, shingraf is used in the treatment of all diseases caused by an excess of phlegm. It is considered very effective in these diseases because its temperament (mizāj) is considered to be hot and dry in the third degree. ${ }^{69}$ Shingraf is also said to be very effective in ulcers of the kidneys (qurūh-e gurdeh) and other malignant ulcers. It is helpful in pain caused by very dry skin and by syphilis. It is also a very strong aphrodisiac. The powder of shingraf is used as a collyrium to cure ophthalmia. ${ }^{70}$

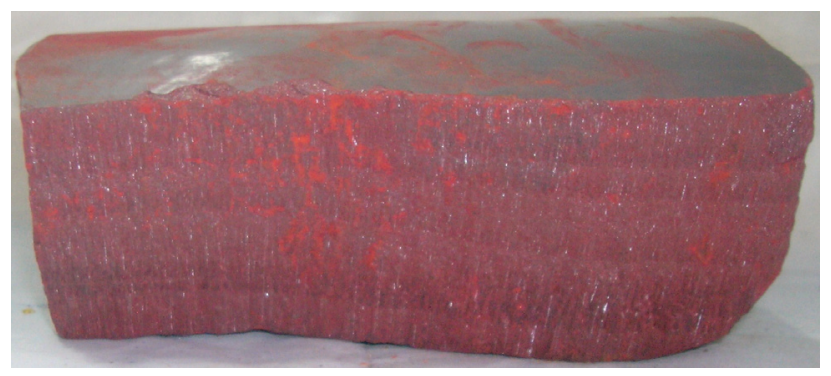

In his famous medical works written in the eighteenth century, M. Akbar Arzānī recommended several mercurial preparations for internal use in several diseases. For external use, he suggested several remedies containing shingraf. In the Qarābādīn-e Qādirñ, Arzānī listed at least four ${ }^{71}$ different prescriptions how to prepare Marham-e shingraf ("ointment of cinnabar"). One of them goes like this:

Take 10 istā $r^{72}$ of shingraf, 5 dirham / drachm (diram) dross of lead (murdā sang), one dirham (each) of gum olibanum (mom kundur), ${ }^{73}$ galbanum (qinna), ${ }^{74}$ gum ammoniac $(u s h \bar{a} q),{ }^{75}$ grind them and melt them altogether in a vessel. Then melt altogether with sesame oil (roghan-e kunjad) or olive oil (zait) to make the marham. ${ }^{76}$

68 Dehlvi 2011: 65.

69 Nașīr Aḥmad Ṭāriq s.d.: 379.

70 Nadkarni 2007: 83.

71 Arzānī 2008: 751, 752, 755.

721 istār $=41 / 2$ miqqāls or $6 \frac{1 / 2}{2}$ drachms. There was no standardisation of weights and measures throughout India until British Colonial times. So the exact weight of one diram also cannot be exactly defined. For the above mentioned definitions see the Urdu dictionary by John Platts (1884).

73 Francincense, i.e. the fragant gum-resin of different kinds of Boswellia.

74 The likewise fragant gum-resin of Ferula gummosa.

75 Ammoniacum, the gum-resin of Dorema ammoniacum.

76 Arzānī 2008: 751-752. 
Like almost all other kinds of (mercurial) ointments, Marham-e shingraf is useful in skin diseases and venereal diseases. Fleming wrote that the native practitioners used shingraf as an antispasmodic and in skin diseases. Then, Fleming stressed that in the beginning of the nineteenth century, people commonly used it as a fumigant in those cases of venereal diseases (syphilis), in which the patients suffered from ulcers of the mouth, nose or throat. In those cases, cinnabar was thrown on red hot iron, and the patient, covered with a blanket, inhaled the fume of the shingraf. ${ }^{77}$

Like the kushta of mercury, the kushta shingraf is also considered a very powerful drug, which is applied in sexual weakness or anaemia. ${ }^{78}$ It is recommended in the treatment of all diseases, which are "cold and wet", meaning diseases caused by an excess of phlegm. This comprised a general weakness or loss of appetite. ${ }^{79}$ Hazārah Khān listed thirty different kinds of kushta shingraf, exactly ten more than those of kushta simāb. ${ }^{80}$ Again, the different kinds of preparations might result in different kinds of action of the kushta, but these are not listed by the author. In the second part of his book Iksīr-e kushta, Bulāqī Das, on the other hand, gave several examples how the kushta shingraf might be further processed in compound drugs. Only one example will be given here. For all compounds, the dose of kushta shingraf as prepared according to the description in part 1 of the book is $1 / 4-1 / 2$ of a ratti.

To be added: one māsha of powder of the spikenard (sufüf-e bālcharir), one māsha of powdered cardamom (ila'ichī) seeds. Mix it with 1 tōla of honey (shahed). This is to be eaten. This is used in treating a weak stomach (zaf'-e me'dah) and leprosy (juzām o-korh). ${ }^{81}$

Shingrāf is thought to have negative side effects (mużirr) for all patients with a hot temperament and is thus not recommended for them. ${ }^{82}$

\section{Raskapūr - Calomel}

Raskapūr - usually spelt raskapoor in India - is another drug of mineral origin. It is the sub-chloride of mercury, also known as calomel. Like cinnabar, calomel

77 Fleming 1810: 51.

78 Nașir Aḥmad Ṭāriq s.d.: 379.

79 Ajmal Khān 1992: 164.

80 Hazārah Khān 1902: 81-86; again Bulāqī Das listed only one preparation: Bulāqī Das (1) 1892: 77-78.

81 Bulāqī Das 1892 (2): 141.

82 Nașīr Aḥmad Ṭāriq s.d.: 379. 
is a mineral, which is only rarely to be found in nature. The Unani Pharmacopoeia of India states:

Raskapoor - The drug occurs in the form of dull white crystalline masses of sub-chloride of mercury. The drug masses occur in the form of flat pieces $2-5 \mathrm{~cm}$, fracture brittle, surface crystalline; taste bitter and odour characteristic. Melting point $164-170^{\circ} \mathrm{C} .^{83}$

The use of calomel was not very popular in European medicine until the $18^{\text {th }}$ and $19^{\text {th }}$ centuries, when the British started using it throughout their Empire. In America, calomel gained fame as "heroic medicine", meaning that the many doctors who supported the humoral medicine, excessively applied bloodletting, enema and other purgatives in order to get the bad humours out of the body. In most cases, calomel and other mercurial preparations were heavily overdosed, and many patients died. ${ }^{84}$

In India, the British also used calomel for treating their soldiers in India. In the $18^{\text {th }}$ and $19^{\text {th }}$ centuries, the majority of British doctors working in India still believed in humoral medicine and were of the opinion that the abundance of bile caused inflammations of the liver and bilious fevers in a tropical environment. ${ }^{85}$ Thus, they used calomel and other mercurial remedies in the treatment of several diseases. During the nineteenth century, the use of calomel in venereal diseases became quite common. As M. Harrison observed in his paper on calomel, calomel was a very popular "bazaar medicine", which became popular throughout the British Empire. ${ }^{86}$

Robert Hamilton Irvine, who was a British Assistant Surgeon in Ajmer (1841) and later a Civil Surgeon in Patna (1848), wrote about the use of calomel:

Raskapur, [Hindi script]: Impure Calomel (Protochloride of Mercury). Comes from Bombay and Delhie: is given in eight grain doses to salivate in the veneral disease, and used in ointments, one seer costs eight rupees. ${ }^{87}$

Seven years later, Irvine added: water. $^{88}$

... used as a purge and in ointments. Dose gr. $1 / 4$ to gr. v. well washed in hot

The British were eager to collect information about the remedies the "native doctors" commonly used and also bought the medicines in the local bazars in

83 Central Council for Research on Unani Medicine (CCRUM) 2010: 262.

84 Swiderski 2008: 64, 132.

85 Harrison 2013, 61.

86 Harrison 2013: 61, 63.

87 Irvine 1841: 149.

88 Irvine 1848: 90. 
order to test them. This interest in Indian materia medica was also shown by J. Fleming, Surgeon of the Bengal Establishment (d. 1829), who gave a detailed account on the process of obtaining raskapūr. He wrote that he received all the information from a Persian medical manuscript, which was translated with the help and support of a certain Dr. Hunter. ${ }^{89}$ Unfortunately, no detailed information was given on the origin of this Persian manuscript. Interestingly, Fleming emphasised that both "Hindu or Muhammadan practitioners" used raskapūr, and that there were various methods of obtaining it which were only slightly different from each other. The translation of the manuscript reads as follows:

Take quick-silver, Armenian Bole, Alum ('some prefer blue vitriol, but alum is better'), Rock Salt, of each nine parts. Rub the whole in a mortar with water, and let them harden. Then put the mass into a glazed earthen vessel; and place inverted, above it, another similar vessel, plastered with ashes, and the milk of D'hathura. ${ }^{90}$ Lute them together with Philosopher's clay, and keep them three days and three nights in a fire made with cow dung. Then let the vessels cool, and take out what adheres to the bottom and sides of the upper vessel. This is the Raskapur. ${ }^{91}$

It is interesting that Dutt stated in the nineteenth century that raskapūr was not prepared according to the processes described in the Sanskrit sources, "but by subliming the black sulphide of mercury with common or rock salt. In this form it is largely manufactured and sold in all the bazars." 92 As we can see from the Persian medical manuscript quoted above, the method of obtaining raskapūr was obviously one of the methods applied by the hakims. Dutt wrote that the use of this kind of calomel was not without risk:

As the Rasa karpura of the bazars is not a pure perchloride of mercury, but is a mixture of calomel and corrosive sublimate in indefinite proportions, the patient sometimes escapes after this dose. When, however, it contains more of corrosive sublimate than of calomel, intense salivation, gastritis and even death may result. When such doses of poisonous remedies are recommended in standard works it is no wonder that we should occasionally come across cases of dreadful salivation, induced by native treatment. The circumstance of wheat-flour being used as a covering to the poison may act as an antidote to some extent. In secondary syphilis Rasa karpura is given in small doses in combination with cloves, saffron, sandalwood, and musk. ${ }^{93}$

89 Fleming 1810: 52.

90 There are several species of Datura used in unani medicine, among them Datura alba, known as Thorn Apple or Devil's Apple in English and as dhatura in Urdu. Indications include arthritis, asthma, fevers, neuralgia or sciatica. See Dehlvi 2011: 93.

91 Fleming 1810: 52.

92 Dutt 1922: 37.

93 Dutt 1922: 37. See also Dagmar Wujastyk in this volume. 
Both calomel and cinnabar were available as small pills, which were used for direct intake or sometimes smoked in pipes. Looking at the medical encyclopaedias, it is obvious that raskapūr is still a very popular drug. Hakīms use several ointments containing it, e.g. Marham-e raskapūr. As the temperament (mizāj) of raskapūr is hot and dry in the fourth degree, it might be considered the most potent and efficacious mercurial remedy of all those mentioned before. It is mainly used in inflammations of the kidneys and in syphilis. ${ }^{94}$

The kushta raskapūr is said to have the same therapeutic actions. It is used in all diseases caused by putrefaction of blood, e.g. leprosy or gonorrhoea. ${ }^{95}$

The recommended dose of raskapūr is 2-4 chāwal, meaning 2-4 grains of rice. In all medical writings analysed, this is the recommended dose. Sometimes it is also mentioned that an overdose has harmful effects, like pustules all over the body (see above). In the following section, the negative side effects of mercury will be discussed.

\section{0 (Negative) side effects of mercury}

It has already been mentioned that Greek authors like Dioscurides and Galen described the negative side effects of mercury and even recommended not to prepare medicines containing mercury for internal use, for example as pills. ${ }^{96}$

As we have already shown in this paper, some hakims in India also abstained from prescribing mercury for internal use, but many hakims prescribe mercurial preparations both for internal and external use. Although mercury, shingraf and raskapūr are commonly prescribed, authors of medical works and encyclopaedias recommend using them carefully. They also advise hakims to prepare mercurial remedies carefully and to "kill" the mercury properly. Some hakims, however, remained critical towards the use of mercury. K.M. Nadkarni, who published his famous work Indian Materia Medica in 1908, combined ayurvedic and unani medicine and listed the most popular home remedies of his time. The work has been published in several editions, and it was changed and extended by the author's son, A.K. Nadkarni. Concerning mercury and its dangers, the book for example, reads:

94 Lōdhī s.d: 217-218.

95 Ajmal Khān 1992: 170-171.

96 On this aspect see Natalia Bachour's paper in this volume. 


\begin{abstract}
In pregnant women mercury leads to abortion, still-births and births of cachectic infants; in children it leads to a low state of the body known as Marasmus, and in adults, to a kind of cachexia characterised by wasted muscles, pale skin and tendency to haemorrhages etc. Over-doses or long continued use of mercury produce a set of symptoms known as mercurialism characterised by symptoms of profuse salivation, swollen and spongy gums, foul breath, swelling of tongue, ulceration of the mouth, lips and tongue, loosening of the teeth etc., etc. ${ }^{97}$
\end{abstract}

The "harmfulness" (mużir), however, is not denied by the authors of unani medical tracts from the early twentieth century onwards. Ḥakim Nașir Ahmad Țāriq stated: "Quicksilver might be harmful for the seminal fluid (munih or manī), the brain (dimāgh), the throat (halq) and the joints (jorūn)." 98 Hakīm Lōdhī wrote that mercury might be harmful to the ear (kān). In case that negative side effects occur, a mușlih, - an "antidote" or "corrector" might be helpful. ${ }^{99}$ Both hakims recommend cow milk (dūdh) and clarified butter (ghee) as an antidote. In the National Formulary of Unani Medicine, ${ }^{100}$ another drug is mentioned against mużarrat-e simāa - the toxicity of mercury. The drug is called jawansa or turanjabin in Urdu. It consists of the dried whole plants of the Persian Manna Plant (Alhagi pseudalhagi Bieb ${ }^{101}$ or Alhagi maurorum), which is also called Arabian manna, Caspian manna or Camel thorn in English. Next to its therapeutic use against toxicity of mercury, hakims use turanjabin for treating bleeding piles. It is known for its antibacterial and antiseptic characteristics (among others) and is considered useful for the suppression of blood impurities and constipation. ${ }^{102}$

\title{
11 The treatment of syphilis
}

It has already been mentioned several times that mercury and all mercurial preparations are used in the treatment of syphilis (Urdu: äteshak).

Following the spread of syphilis in the Islamic world from the fifteenth century onwards, hakims began to deal with what most authors regarded as a new disease in medical encyclopaedia.

97 Nadkarni 2007 (2): 74.

98 Nașir Aḥmad Ṭāriq s.d.: 183.

99 Lōdhī s.d.: 266.

100 CCRUM 2006 Part I: vol vi, 37.

101 The name Alhagi is derived from the Arabic word al-hājjī, which means a person who has performed the Islamic ritual pilgrimage to Mecca (hajj).

102 Dehlvi 2011: 11-12. 
In the sixteenth century, 'Imād ud-Dīn Shirāzī (fl. ca. 1569) ${ }^{103}$ wrote a monograph in Persian, Risāla-yi äteshak, ("Treatise on Syphilis") which was also well known in India. Following humoral theory, 'Imād ud-Dīn stated that atteshak was caused by an excess of black bile. He further elaborated that infection occurred through sexual intercourse or through contact with the exhalation of people afflicted by it. 'Imād ud-Dīn also discussed treatment with mercury and the risks of it. While syphilis had already been known to hakims for centuries, the British presence and the spread of "allopathy" in the nineteenth century stimulated hakims to do further research of the competing medical traditions on the disease. The treatment of gonorrhoea, syphilis and other venereal diseases became the subject of several encyclopaedias or books. One very interesting example of this kind of literature is the Risāla-yi dāf'-e àteshak in Urdu, meaning "Treatise on Repelling Syphilis", written by Ḥakìm Ghulām Nabī and Ḥāfiz Fakhr ud-Dīn and published in 1879. On the English title page of the book, it is mentioned that the book is "[a] concise history and description of those affections and their treatment, both English and Oriental." It is worth noting that - like in many Urdu books of the same time - English medical terminology is transcribed in Urdu and that several English doctors are also quoted. For example, the English word periostitis (inflammation of the periosteum) is transcribed as pari- $\bar{a} s-\hat{t} \bar{a}-\bar{a}$ ' $-\hat{t} i s$ and explained as "inflammation" (sozash) in the bone (asthi). The authors correctly point out that when a pregnant woman is infected with syphilis, the child might suffer from periostitis. The authors however advise against the use of mercury in the treatment of pregnant women. ${ }^{104}$

In the first chapter of the Risāla-yi dāf'-e àteshak, the question whether syphilis was already known to the doctors of past times is discussed, and 'Imād ud-Dīn's theories are also mentioned. Then, the different names of the disease are listed, and it is mentioned that it originated in Europe (yürop) and was spread by Europeans (farang) to the Arabic world. After that, the three main stages (sg. daraja) of syphilis are explained and the symptoms ('alamāt) and the treatment ('ila $\bar{j}$ ) are described. Detailed prescriptions of compound drugs are given, most of which are unani formulas and contain mercury. The authors recommend three different ways of treatment with mercury in the treatment of the primary syphilis: fumigation, ointment of mercury and inner application.

First, the authors recommend fumigation (hawānī) therapy, which is called "Turkish Bath" (hammām) in the Ottoman Empire. The patient is told to take a

103 See Kurz and Reichmuth 2012: 240-242.

104 Ghulām Nabī and Fakhr ud-Dīn 1879: 48. 
seat on a chair (kursī). Then, his whole naked body - except his face - is covered by a blanket. Below the chair, a big brick, which was well heated is placed. Then, five rattì of kushta sīmāb kìlomel (calomel) are "dissolved" on the brick, until the mercury is absorbed by the body of the sick person and his gums soften. This will take around fifteen minutes and has to be done every day in the evening for three to four weeks.

The second therapy with mercury mentioned by the authors is that of Marham-e simāb, the ointment of mercury, which has to be applied daily on the skin of the elbows and knees. The third method of treatment of primary syphilis is the intake of compound mercurial preparations. The medicines are given to the patient as a powder (sufüf) or a pill (golā). The mercury should be given together with opium, for example, one grain of calomel with one grain of opium (afyūn). This should be taken in the morning and in the evening, and the dose of mercury should not exceed 52 rattī or five grains.

In the following chapters on the treatment of secondary and congenital syphilis, many other formulations containing mercury are given. Most compound drugs are unani preparations, some ayurvedic and "allopathic" preparations are also given. ${ }^{105}$ Next to mercury, the use of the china root (chub-e chinī) is recommended in the treatment of syphilis. ${ }^{106}$ The fact that the authors mention the use of mercurial preparations in the three medical traditions of unani, ayurveda and allopathy gives a good sense of the medical pluralism in nineteenth century India.

Today, ateshak remains the main indication for the use of most of the mercurial preparations listed by the CCRUM. The CCRUM recommends the use of mercurial pills and powders only, but other sources describe the usefulness of mercurial fumigation therapies. For example, the National Institute for Industrial Research recommended the following fumigation therapy in the treatment of syphilis:

For (Mercury fumigation) fumigation in primary syphilis: Mercury, sulphur and rice, each 192 grains, are pounded together and made into a paste. The syphilitic is subjected to the fumigation by seven days, by putting each part into fire each day; - about half a drachm of the black sulphide mixed with a $1 / 4$ part of wheat-flour is employed daily for seven days in succession. ${ }^{107}$

Unfortunately, there is no reliable data on the use of these fumigation therapies by present-day hakims, so that it cannot be stated if these therapies are still in use at all.

105 Ghulām Nabī and Fakhr ud-Dīn 1879: 48.

106 Ghulām Nabī and Fakhr ud-Dīn 1879: 18-21. It would be beyond the scope of this article to mention all the Persian treatises on China root - this should be subject of further research.

107 NIIR s.d.: 473. 


\section{Concluding remarks}

The use of mercury in unani medicine is regarded as derived from the GraecoArabic heritage on the one hand and as an adaptation of uses in the Indian ayurvedic and alchemical traditions on the other hand by practitioners of unani. While some authors like Sharif Khān remained sceptical about the internal use of mercury, other hakīms like Muhammad Akbar Arzānī propagated the use of mercurial preparations for both internal and external use. Apart from the different kinds of kushta simmāb, cinnabar and calomel are still very popular in unani medicine. The question if these kushtas of unani medicine and the bhasmas of ayurvedic medicine are similar or even identical, should be subject of further research of scientists who can translate the relevant prescriptions from Sanskrit, Persian and Urdu. By means of these translations, it might be possible to discuss the question if the internal use of mercury and other mineral drugs is rooted in the Graeco-Arabic medical tradition or in the Indian alchemical or ayurvedic traditions - or if they were even developed conjointly.

Acknowledgements: This paper was written as part of my work in the research project "Medical Knowledge and Plural Culture: Graeco-Islamic Medicine (tibb-i yūnānī, Unani Medicine) and its representation in South-Asia” at the RuhrUniversity Bochum, Germany (2008-2015; Prof. Dr. Stefan Reichmuth).

Funding: The project was funded by the German Research Foundation (DFG). I am indebted to Mohsin Dehlvi (Delhi) for reading an earlier draft of this paper and offering me his expertise.

\section{References}

Ajmal Khān (1992): Șinā'at at-taklīs (The Art of Calcination). 3rd ed. Lāhōr: Idāra-ye Mațbu‘āt-e Sulaymānī.

Alavi, Seema (2008): Islam and Healing: Loss and Recovery of an Indo-Muslim Medical Tradition. [2007]. New Delhi: Permanent Black.

Arnold, David (2002): Colonizing the Body: State Medicine and Epidemic Disease in NineteenthCentury India. [1993]. Berkeley: University of California Press.

Arzānī, Muḥammad Akbar (2008): Qarābādīn-e Qādirī: Urdū tarjama (The Pharmacopoeia of Qādir: Urdu translation), Nā'ī Dehlī: CCRUM.

Attewell, Guy (2007): Refiguring Unani Tibb: Plural Healing in Late Colonial India. New Delhi et al.: Orient Longman.

Azmi, Altaf A. (1995): Basic Concepts of Unani Medicine. A Critical Study. New Delhi: Jamia Hamdard. 
Aqīlī, Khorasānī (1844): Makhzān al-adwiya. (Store-house of Medicines). Vols. II Calcutta: Reprint Teheran 1355-1371 h.s. (1976-1992).

Bulāqī Das (1892): Iksīr-e kushta (The Elixir of kushta). Delhī: Mațba‘ Mewār Prīs (Mewar Press). Central Council for Research on Unani Medicine (CCRUM) (2006): National Formulary of Unani Medicine, Part I. Reprint. New Delhi: Government of India, Ministry of Health (Department of AYUSH).

Central Council for Research on Unani Medicine (CCRUM) (2007): National Formulary of Unani Medicine, Part II, Vol. I. New Delhi: Government of India, Ministry of Health (Department of AYUSH).

Central Council for Research on Unani Medicine (CCRUM) (2012): Standard Unani Medical Terminology. New Delhi: Government of India, Ministry of Health (Department of AYUSH). In collaboration with World Health Organization Country Office for India.

Central Council for Research on Unani Medicine (CCRUM) (2010): The Unani Pharmacopoeia of India. Part II, Vol. II. 1st ed. New Delhi: Government of India, Ministry of Health (Department of AYUSH).

Dehlvi, Mohsin (2011): Individual Profiles of Herbs, Minerals and Animal Products. New Delhi: Dehlvi Naturals.

Dutt, Uday Chand (1922): The Materia Medica of the Hindus. Rev. ed. Calcutta: Dass.

Elgood, Cyrill (1931): "Translation of a Persian Monograph on syphilis entitled "Risála-iÁtishak” by Imád-ul-Din Maḥmúd Bin Mas‘úd Bin Maḥmúd-ul-Ṭabíb”. Annals of Medical History 3: 465-486.

Fleming, John (1810): A Catalogue of Indian Medicinal Plants and Drugs, with their names in Hindustani and Sanskrit Language. Calcutta: Hindustani Press.

Ḥamīd ud-Dīn (1902): ‘Aqd as-sīmāb (The Binding of Mercury). Jaunpūr.

Ghulam Nabi, Hakim and Fakhr-du-Din (1879): Urdoo Manual of Venereal Diseases: A concsie (sic!) history and description of those affections and their treatment, both English and Oriental. (Risāla-ye dāfi'-ye äteshak: Treatise on Syphilis). Lahore.

Harrison, Mark (2013): "From Bazaar Medicine to Hospital Medicine: Calomel, India and the British Empire, c. 1750-c. 1800”. In: Medical Encounters in British India. Edited by Deepak Kumar and Raj Sekhar Basu: New Delhi: OUP, 61-79.

Hassan, A.Y. al-/Ahmed, Maqbul/ Iskander, A.Z. (2001): Science and Technology in Islam: the Applied Sciences (The Different Aspects of Islamic Cultures; 4). Paris: United Nations Educational.

Hazārah Khān (1902): Kushtajāt-e Hazārī (The kushtas of Hazārah). Lāhōr: Mațba'-ye Shams.

Hoodbhoy, Pervez A. (1992): Islam and Science: Religious Orthodoxy and the Battle for Rationality. London: Zed Books.

Ibn Sīnā, Abū 'Alī: al-Qānūn fi-ț-țibb (1593): Kitāb 1-5. Rūm. Saab Digital Library, American University of Beirut. http://ddc.aub.edu.lb/projects/saab/avicenna/ (24/07/2015)

Irvine, Robert Hamilton (1848): A Short Account of the Materia Medica of Patna. Calcutta: W. Ridsdale, Military Orphan Press.

Irvine, Robert Hamilton (1841): Some Account of the General and Medical Topography of Ajmeer. Calcutta: W. Thacker \& Co.

Kurz, Susanne, Reichmuth, Stefan (2012): "Zwischen Standardisierung und Literalisierung: Der Fallbericht in der graeco-islamischen Medizin”. In: Der Ärztliche Fallbericht. Epistemische Grundlagen und textuelle Strukturen dargestellter Beobachtung. Edited by Rudolf Behrens and Carsten Zelle. Wiesbaden: Harrassowitz, 227-258. 
Lōdhī, Ḥakīm Muḥammad Anwār Khān (s.d.): Makhzān al-mufradāt (The Treasurehouse of Single Drugs). Lahōr: Muḥammad Bashīr \& Sons.

Meer, Tufayl Aḥmad (1959): Tuhfa-ye Khānī. (Gift to the Ruler). Madras: Government Oriental Manuscripts Library.

Nadkarni, Krishanrao M. (2007 [1908]): Dr. K.M. Nadkarni’s Indian Materia Medica: With Ayurvedic, Unani-Tibbi, Siddha, Allopathic, Homeopathic, Naturopathic \& Home Remedies, Appendices \& Indexes. 3rd ed. Edited by K.M. Nadkarni, revised and enlarged by A.K Nadkarni. Vols. 1-2. Bombay: Popular Prakashan.

National Institute for Industrial Research (NIIR) (ed.) (s.d.): Hand Book [sic!] On Unani Medicines with Formulae, Processes, Uses and Analysis. Delhi: Asia Pacific Business Press.

Platts, John (1884): A Dictionary of Urdu, Classical Hindi, and English. 2 vols. London: W.H. Allen \& Co.

Preckel, Claudia (2015): "Yūnānī Medicine”. In: Encyclopedia of Indian Religions. Islam. Edited by Arvind Sharma. New Delhi: Springer India.

Rampūrī, Muḥammad Najm ul-Ghanī (s.d.): Khazā'in al-adviya: sā'inklōpīdiyā āf îstirn mēdīsīn (Treasures of Medicine: Encyclopaedia of Eastern Medicine). Vol. 1-4. Lāhōr: Muhammad Bashīr \& Sons.

Sharmā, Krishan Kinwar Dutt (s.d.): Kanz at-taklīs (Treasure of Calcination). Lāhōr: Idāra-yi Mațbu‘āt-e Sulaymānī.

Speziale, Fabrizio (2009a): “India. xxxiii. Indo-Muslim physicians”. In: Encyclopaedia Iranica, online edition, www.iranicaonline.org.

Speziale, Fabrizio (2009b): "Islamic or Yunani? Past and Present of Muslim Traditional Medicine in the Deccan Sultanates". In: Global Medical Geography. In Honour of Prof. Yola Verhasselt. Edited by Rais Akhtar and Nilofar Izhar. Jaipur et. al.: Rawat, 277-305.

Speziale, Fabrizio (2009c): "Šarīf Khān”, in: Encyclopaedia Iranica, online edition, www.iranicaonline.org.

Speziale, Fabrizio (2010): Soufisme, religion, et medicine en Islam indien. Paris: Karthala.

Swiderski, Richard M (2008): Quicksilver: A History of the Use, Lore and Effects of Mercury. Jefferson et al.: McFarland \& Co.

Tariq, Mohd et al. (2013): "Introduction to Kushta: a Herbo-Mineral Formulation”. Journal of Pharmaceutical and Scientific Innovation 2.1: 14-17.

Tariq, Mohd. (2014): The Science and Art of Kashtasazi (Taklees): Basic concepts and analytical Theory. Saarbrücken: LAP Lambert Academic Publ.

Ṭāriq, Nașīr ud-Dīn (Ḥakīm) (s.d.). Tahqīqāt khawāṣṣ al-adwīya (Inquiries into the qualities of medicines) Lāhōr: Maktaba Daniyāl.

White, David M. (1996): The Alchemical Body: Siddha Traditions in Medieval India. Chicago et. al.: University of Chicago Press.

Wujastyk, Dagmar (2013): “Perfect Medicine: Mercury in Sanskrit Medical Literature”. Asian Medicine 18: 15-40.

Ẓillur Raḥmān, Ḥakīm Sayyid (2001): "Unani Medicine in India: Its Origin and Fundamental Concepts". In: History of Science, Philosophy and Culture in Indian Civilization, Vol. 4, 2. Medicine and life sciences in India. Edited by Bidare V. Subbarayappa. New Delhi: Munshiram Manoharlal, 292-325.

Ẓillur Raḥmān, Ḥakīm Sayyid (2009): Jadīd yūnānī dawāsāzī (New/Modern Unani Pharmacy). New Delhi: Idara Kitab-ul-Shifa. 